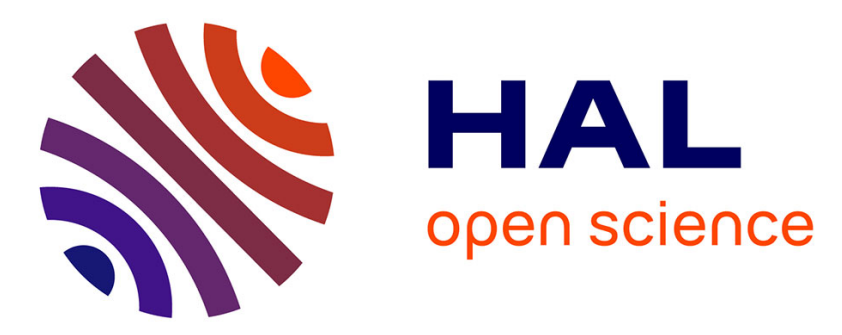

\title{
Supramolecular gels derived from nucleoside based bolaamphiphiles as a light-sensitive soft material
}

Julie Baillet, Alexandra Gaubert, Dario M Bassani, Julien Verget, Laurent Latxague, Philippe Barthélémy

\section{To cite this version:}

Julie Baillet, Alexandra Gaubert, Dario M Bassani, Julien Verget, Laurent Latxague, et al.. Supramolecular gels derived from nucleoside based bolaamphiphiles as a light-sensitive soft material. Chemical Communications, 2020, 56 (23), pp.3397 - 3400. 10.1039/d0cc00336k . hal-03032711

\section{HAL Id: hal-03032711 \\ https://hal.science/hal-03032711}

Submitted on 2 Nov 2021

HAL is a multi-disciplinary open access archive for the deposit and dissemination of scientific research documents, whether they are published or not. The documents may come from teaching and research institutions in France or abroad, or from public or private research centers.
L'archive ouverte pluridisciplinaire HAL, est destinée au dépôt et à la diffusion de documents scientifiques de niveau recherche, publiés ou non, émanant des établissements d'enseignement et de recherche français ou étrangers, des laboratoires publics ou privés. 


\section{Supramolecular gels derived from nucleoside based bolaamphiphiles as a light-sensitive soft material}

Received 00th January 20xx, Accepted 00th January 20xx DOI: $10.1039 / x 0 \times x 00000 x$

\author{
Julie Baillet, ${ }^{a}$ Alexandra Gaubert, ${ }^{\mathrm{a}}$ Dario M. Bassani, ${ }^{\mathrm{b}}$ Julien Verget, ${ }^{\mathrm{a}}$ Laurent Latxague* ${ }^{\mathrm{a}}$ and \\ Philippe Barthélémy*a
}

\begin{abstract}
Light-sensitive Low Molecular Weight Gelators (LMWGs) derived from glyconucleoside bolaamphiphiles containing a stilbene unit displayed gelation abilities in hydroalcoholic mixtures. These materials showed a gel-sol transition under UV irradiation thanks to $E-Z$ isomerization of stilbene and could find potential applications as drug delivery systems.
\end{abstract}

Supramolecular gels resulting from the self-assembly of functional low molecular weight gelators (LMWGs) have gained an increasing interest in many fields ranging from tissue engineering to electronic devices. ${ }^{1-6}$ The dynamic nature of non-covalent interactions represents a powerful tool to modulate the physical behavior of LMWGs. Many changes or modifications, occurring at the molecular level (supramolecular structure, geometry) and / or at the macroscopic scale (gel - sol states, physico-chemical properties) have been reported. ${ }^{7,8}$ According to their hydrophilic to hydrophobic balance among other parameters, LMWGs can provide hydro-, organo- or oleogels. Falling between hydro- and organogels, hydroalcoholic gels are of particular interest for the formulation of various active pharmaceutical ingredients (APIs) as antiinflammatory (including non-steroid molecules), ${ }^{9,10}$ anti-epileptic ${ }^{11}$ or antifungal ${ }^{12}$ drugs. However, these gels are mainly composed of mixtures of synthetic or natural polymers and penetration enhancers. In the last decade, responsive supramolecular gels sensitive to enzymes, ${ }^{13-16}$ magnetic/electric fields, ${ }^{17,18}$ or $\mathrm{pH}^{19,20}$ among other triggers have been extensively designed for diverse applications ranging from controlling cell behavior ${ }^{21}$ to drug release. ${ }^{22}$ Recently, light stimulation has attracted much attention as a minimally invasive stimulus allowing precise spatiotemporal

\footnotetext{
a. J. Baillet, Dr. A. Gaubert, J. Verget, Dr. L. Latxague, Prof. P. Barthélémy University of Bordeaux, INSERM U1212, UMR CNRS 5320, F-33076 Bordeaux (France)

E-mail: philippe.barthelemy@inserm.fr; laurent.latxague@u-bordeaux.fr

${ }^{b .}$ Dr. D. M. Bassani

University of Bordeaux, CNRS, Bordeaux INP, ISM, UMR 5255, F-33400 Talence

(France)

Electronic Supplementary Information (ESI) available: [details of any supplementary information available should be included here]. See DOI: $10.1039 / x 0 x \times 00000 x$
}

control and has successfully been applied in nanotechnology or biomedicine. ${ }^{23-25}$. Light-responsive gels generally rely on the presence of photochromic moieties that undergo ring-opening / closing reactions (spiropyrans, diarylethenes) or $E / Z$ isomerization (azobenzene, stilbene and derivatives). ${ }^{26-34}$ Stilbene has been particularly studied thanks to its well-known photoswitching behavior $^{35}$ to give light-sensitive gels based on cholesterol, ${ }^{36}$ oxalyl amide, ${ }^{37,38} \mathrm{~N}, \mathrm{~N}^{\prime}$-dimethyldodecylamine ${ }^{39}$ or amino acid ${ }^{40}$ derivatives displaying gel-sol or sol-gel transitions under irradiation. To the best of our knowledge, hydroalcoholic supramolecular gels sensitive to an external stimulus such as light have not been reported so far. These materials could be used as models for drug delivery in the case of external use for example. However, the design of such stimuli-sensitive gels can profoundly impact the likelihood of successful gel responsiveness for a given application. The introduction of large hydrophobic photochromic units in a LMWG framework may disturb the self-assembly process and imped effective photoisomerization in gel state due to steric hindrance. This behavior might be accentuated when photosensitive moieties are simultaneously tightly packed and strongly involved in the supramolecular assembly. ${ }^{41,42}$

Bio-inspired amphiphilic substrates combining carbohydrate, nucleoside and lipid units have shown promising applications as LMWGs. ${ }^{43-46}$ Among them, bolaamphiphiles derivatives in which two glyconucleoside headgroups are linked covalently by a hydrophobic spacer have emerged as attractive scaffolds for biomedical applications. ${ }^{47-49}$ In this work, we present a series of light-sensitive supramolecular gels based on glyco-nucleosidebolaamphiphile derivatives (GNBAs) featuring a thymidine, a glucose or a lactose and a stilbene, as photochromic moiety, within the hydrophobic part. The resulting responsive GNBAs led to the formation of thixotropic gels in hydroalcoholic solvents and a photoinduced gel-sol transition upon irradiation due to the stilbene photoisomerization.

A synthetic route was developed in 6 steps based on CUAAC chemistry / metathesis reactions, starting from commercial thymidine (Scheme $1 \mathrm{~A})$. The introduction of a propargyl unit at the N3 position under microwave conditions allowed the formation of N3-propargylthymidine 1 . The latter was then submitted to a CUAAC reaction with the desired peracetylated azidosugar to form 
the corresponding 1,2,3-triazole derivative, followed by the $5^{\prime}$ position functionalization with an azide group. Intermediates $\mathbf{3}$ and $\mathbf{3}^{\prime}$ ' were then involved in a second CUAAC reaction with the desired propargylic carbon chain $\mathbf{6 a}$ or $\mathbf{6 b}$ gathering a styrene ending group to form the corresponding glyconucleolipids. E-bolaamphiphile structures were then obtained via the stereoselective homometathesis reaction using the Hoveyda-Grubbs II catalyst. Deprotection of the acetyl sugar groups under basic conditions allowed to reach the final general structure 9. Using this strategy, three GNBAs 9a, 9'a, 9'b, displaying different hydrophobic chain lengths and sugar moieties, were synthetized (Scheme 1B).
A

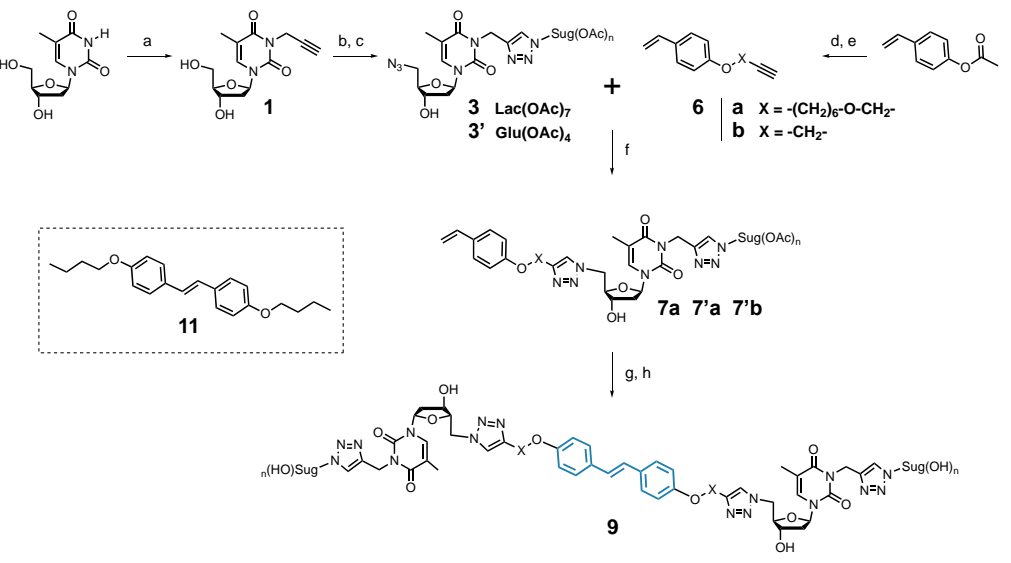

B

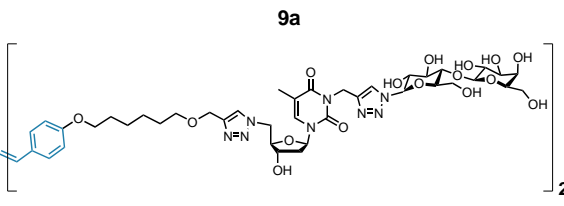

9'a

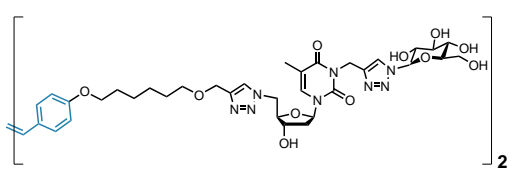

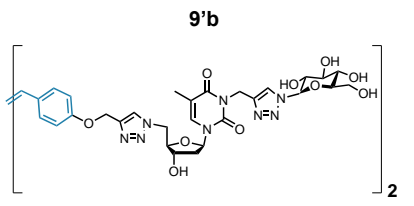

Scheme 1. Synthetic route leading to light-sensitive bolaamphiphiles (A) and chemical structures of GNBAs 9a, 9'a and $\mathbf{9}^{\prime} \mathbf{b}$ (B)

Reagents and conditions: a - $\mathrm{NaH}$ (60\% dispersion in oil, 1.15 equiv), propargylbromide ( $80 \%$ wt. in toluene, 1.2 equiv), anhydrous $\mathrm{DMF}, 45$ min, microwaves, $84 \%$; $\mathbf{b}$ Peracetylated azidosugar (1 equiv), $\mathrm{CuSO}_{4}, 5 \mathrm{H}_{2} \mathrm{O}$ (0.1 equiv), sodium ascorbate (0.2 equiv), ${ }^{t} \mathrm{BuOH} / \mathrm{H}_{2} \mathrm{O}(1: 1), 15 \mathrm{~h}, 65{ }^{\circ} \mathrm{C}, 64-71 \%$; $\mathrm{c}-\mathrm{PPh}_{3}\left(1.2\right.$ equiv), $\mathrm{NaN}_{3}\left(5\right.$ equiv), $\mathrm{CBr}_{4}(1.2$ equiv), anhydrous DMF, $24 \mathrm{~h}, \mathrm{RT}, 61-71 \%$; $\mathbf{d}-\mathrm{KOH}$ aqueous solution (1.5 M, 2.5 equiv), $4 \mathrm{~h}, 0{ }^{\circ} \mathrm{C}$; e - alkyl alcohol (1.2 equiv), $\mathrm{K}_{2} \mathrm{CO}{ }_{3}(1.2 \mathrm{equiv})$, anhydrous $\mathrm{DMF}, 48 \mathrm{~h}, \mathrm{RT}$; $\mathbf{f}-$ Propargylic chain (1.1 equiv), $\mathrm{CuSO}_{4}, 5 \mathrm{H}_{2} \mathrm{O}$ (0.1 equiv), sodium ascorbate (0.2 equiv), ${ }^{\mathrm{t}} \mathrm{BuOH} / \mathrm{H}_{2} \mathrm{O}(1: 1), 15 \mathrm{~h}, 65{ }^{\circ} \mathrm{C}, 83-90 \%$; $\mathrm{g}$ - Hoveyda Grubbs II catalyst (0.05 equiv), anhydrous $\mathrm{DCM}, 16 \mathrm{~h}, 40{ }^{\circ} \mathrm{C}, 27-47 \%$; $\mathrm{h}$ - Sodium methoxide solution (1M in anhydrous $\left.\mathrm{MeOH}\right)$, anhydrous $\mathrm{DCM} / \mathrm{MeOH}$, $1-2 \mathrm{~h}, \mathrm{RT}, 51-70 \%$.

The $E$-configuration of the stilbene chromophore was assessed from ${ }^{1} \mathrm{H}$ NMR of the model structure (11). Chemical shifts associated to aromatic $(\delta=6.85-6.91$ and $7.38-7.45 \mathrm{ppm})$ and ethylenic protons $(\delta=6.92 \mathrm{ppm})$ are in agreement with the sole formation of the $E$ isomer as reported in the literature. ${ }^{50}$ Thus, no signal corresponding to the Z-stilbene configuration was detected (Figure SI7). The photoresponse of $\mathbf{1 1}$ in $\mathrm{MeOH}$ and DMSO solutions was investigated using monochromatic UV irradiation at $336 \mathrm{~nm}$ (Figure 2 and S(10). The spectral changes were monitored by UV-Vis and NMR spectroscopy to determine the temporal evolution of the absorbance and composition of the samples. During irradiation, the absorbance at long wavelength was found to decrease in agreement with photoinduced $E-Z$ isomerization.

In the case of $\mathbf{1 1}$, the composition of the photostationary state (PSS) was determined by ${ }^{1} \mathrm{H}$ NMR to be 0.15 and $0.28(E: Z)$ in $\mathrm{MeOH}$ and DMSO respectively (Figure SI14, Table SI15). The greater proportion of $E$-isomer in DMSO reflects a greater efficiency for the $\Phi_{Z \rightarrow E}$ process in this solvent and some solvatochromism of the $Z$-isomer. However, the isomerization $E$ - $Z$ was moderately sensitive to solvent effects $\left(\Phi_{E \rightarrow Z}=0.37\right.$ in $\mathrm{MeOH}$ and 0.39 in DMSO). Calculated quantum yields $\Phi_{E \rightarrow z}$ of bolaamphiphiles 9a, 9'a, 9'b were found to be $0.31,0.30$ and 0.36 respectively. These values are similar to $\Phi_{E \rightarrow Z}$ of $\mathbf{1 1}$ in DMSO, indicating a limited impact of the two glyconucleoside heads on the photoisomerization process (Table SI15, Figures SI11-SI13). The photoisomerization was also qualitatively observed in FT-IR experiments on the intermediate 12. Characteristic bands of E-configuration at $965.2 \mathrm{~cm}^{-1}$ and $940.1 \mathrm{~cm}^{-1}$ (C-H bending vibration) decreased in intensity after irradiation combined with the appearance of a new band at $879.4 \mathrm{~cm}^{-1}$ (C-H bending vibration), corroborating the $E$ - $Z$ transition (Figure SI16).

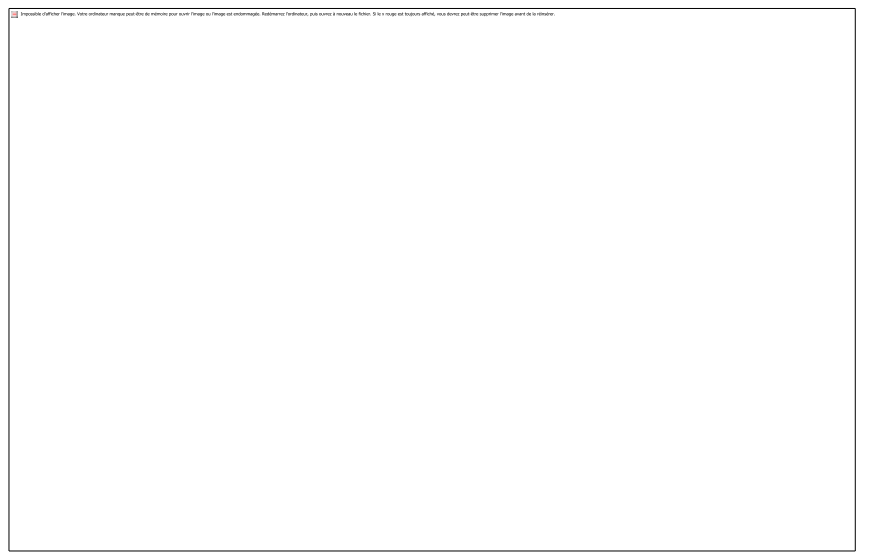

Figure 2. Spectral changes in the electronic absorption spectrum of $11(88.0 \mu \mathrm{M}$ in DMSO) upon irradiation at $336 \mathrm{~nm}$ and the variation of the composition of the solution versus irradiation time.

The gelation abilities of bolaamphiphiles 9a, 9'a and 9'b were evaluated in organic and aqueous solvents. All molecules were insoluble in organic solvents but different behavior were noticed in polar solvents (Table SI17). While $\mathbf{9}^{\prime} \mathbf{b}$ did not form any 
supramolecular assemblies, 9a and 9'a in water / ethanol mixtures led to gels of qualitatively different stabilities based on the qualitatively inversion test tube method. The viscoelastic moduli G' and G" of 9a and 9'a based-gels at $5 \%(\mathrm{w} / \mathrm{v})$ and $2 \%(\mathrm{w} / \mathrm{v})$ respectively in $\mathrm{H}_{2} \mathrm{O} / \mathrm{EtOH}(1: 1)$ were measured by oscillatory rheology. Over the entire frequency range, $\mathrm{G}^{\prime}$ exceeded more than five times $G$ " and values displayed a weak dependence, indicating a solid-like behavior ( $G^{\prime}=64.4 \pm 5.7 \mathrm{kPa}$ for $9 \mathrm{a}$ and $8.0 \pm 0.9 \mathrm{kPa}$ for 9'a at $1 \mathrm{~Hz}$; Figure 3). Interestingly, at the same molar concentration $(13.25 \mathrm{mM} ; 2.4 \%(\mathrm{w} / \mathrm{v}))$, G' values of $9 \mathrm{a}$ based-gel $(30.0 \pm 2.6 \mathrm{kPa}$ at $1 \mathrm{~Hz}$ ) remained higher than $\mathbf{9}$ 'a indicating a stiffer material probably due to an increase of hydrogen bonding capabilities provided by the lactose moieties (Figure SI19). Besides, both gels showed thixotropic properties. This behavior was first estimated using rheology by applying successive low (inside the LVR region) / high strain values (above the flow point, $50 \%$ ) to disrupt the 3D network until the flow and test its recovery ability when the high strain is stopped. A high strain led to an immediate collapse of gels as G" became superior to $\mathrm{G}^{\prime}$ but instantaneously after its removal, $\mathrm{G}^{\prime}$ recovered nearly $70 \%$ of its initial value and reached $100 \%$ in 50 minutes (Figure 3). This behavior was then evaluated by gel extrusion through a syringe and the gel state was confirmed by a $\mathrm{G}^{\prime}$ value superior to $\mathrm{G}$ " (SI video, Figure SI20). Finally, high transition temperatures from gel to sol were measured at $54{ }^{\circ} \mathrm{C}(9 a)$ and $60{ }^{\circ} \mathrm{C}$ (9'a) (Figure SI18).

Transmission electron microscopy performed on bolaamphiphiles 9a and 9'a based-gels at $5 \%(\mathrm{w} / \mathrm{v})$ and $2 \%(\mathrm{w} / \mathrm{v})$ respectively exhibited similar entangled network composed of helicoidal nanofibers of around $20 \mathrm{~nm}$ in diameter and $140 \mathrm{~nm}$ in pitch (Figures 4 and SI22).

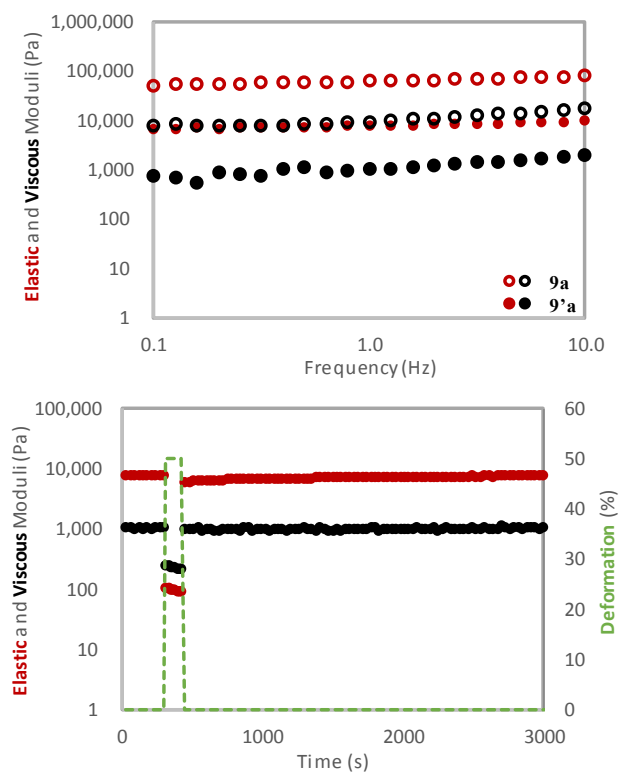

Figure 3. Frequency sweep experiments on 9a and 9'a based-gels at $5 \%(\mathrm{w} / \mathrm{v})$ and $2 \%$ (w/v) respectively (constant strain: $0.05 \%$ for $9 a$ and $0.02 \%$ for 9 'a) and step-strain assay on 9'a based-gel at $2 \%(\mathrm{w} / \mathrm{v})$ (constant frequency: $1 \mathrm{~Hz}$, successive cycles: 1 ) strain of $0.02 \%$ for 5 minutes, $2 /$ strain of $50 \%$ for 2 minutes, $3 /$ identical to $1 /$ for 60 minutes).
To investigate the potential of these systems as light-sensitive materials, gels were submitted to UV light. Irradiation at $336 \mathrm{~nm}$ allowed the destruction of supramolecular architectures to form liquid solutions caused by the expected photoisomerization of $E$ stilbene. However, the rigidity conferred by the interpenetrating network led to a slow process ( 5 to 6 hours). Irradiation with a more powerful lamp at $312 \mathrm{~nm}$ allowed to reduce the time of exposure to 2 hours even if the proportion of $Z$-isomer in the PSS was lower at this wavelength (PSS $=0.54$ for $\mathbf{1 1}$ in solution in DMSO). Liquid states highlighted a network of smaller nanofibers in transmission electron microscopy, responsible thereby for the absence of gelation (Figure 4).
Figure 4. Transmission electron microscopy images of $9 a$ based-gel at $5 \%(w / v)$ (A) and 9'a based-gel at $2 \%(\mathrm{w} / \mathrm{v})$ (B) before and after UV irradiation at $312 \mathrm{~nm}$. Scale bars: 2 $\mu \mathrm{m}$ and $1 \mu \mathrm{m}$.

As a gel-sol transition was observed in response to light-stimuli, we would expect the $E-Z$ transition and a majority of $Z$-isomer in solution states. UV spectra of irradiated $\mathbf{9 a}$ and $\mathbf{9}$ 'a gels at $312 \mathrm{~nm}$ exhibited a $Z$-isomer pattern due to the $\pi->\pi^{*}$ electronic transitions, indicating therefore the proper photoisomerization (Figure SI23). Besides, the absorbance measured at the maximum of absorption of the $E$-isomer $(332 \mathrm{~nm})$ allowed to estimate the proportion of $E$ - and $Z$-isomers after irradiation. A high proportion of $Z$-isomer, estimated at $75 \%$, was highlighted in both case. This result suggested that the complete destruction of the supramolecular architecture into sol states required a similar proportion of Z-isomer calculated in the PSS in solution.

In this study, we have synthesized GNBAs featuring a photo switchable stilbene moiety as light-sensitive LMWGs. The selfassembly of 9a and 9'a in water / ethanol mixture at low concentrations $(\leq 5 \% \mathrm{w} / \mathrm{v})$ revealed the formation of fibrillar networks. Besides, these physical gels featured high elastic moduli (higher than $60 \mathrm{kPa}$ in the case of 9a), thixotropic properties and 
gel-sol transitions compatible with biomedical applications. By using photosensitive GNBAs, in which the stilbene moiety changed its configuration from $E$ to $Z$ under irradiation, the self-assembly could be controlled by UV light leading to macroscopic changes i.e. gel-sol transition. These new supramolecular responsive hydroalcoholic materials could be an alternative to the existing polymer baseddrug delivery systems for external use as the UV light stimulation may provide a faster drug release when needed.

The authors thank the Bordeaux Imaging Center (BIC) and Dr Marc Biran (RMSB, Bordeaux) for technical assistance during TEM observations and NMR experiments. HRMS were performed at IECB, Bordeaux. J.B. thanks the Agence Innovation Defense (AID) for her Ph.D. grant.

\section{Conflicts of interest}

There are no conflicts to declare.

\section{Notes and references}

1 L. A. Estroff and A. D. Hamilton, Chem. Rev., 2004, 104, 12011218.

2 A. R. Hirst, B. Escuder, J. F. Miravet and D. K. Smith, Angew.

Chem. Int. Ed. Engl., 2008, 47, 8002-8018.

3 X. Du, J. Zhou, J. Shi and B. Xu, Chem. Rev., 2015, 115, 1316513307.

4 J. Zhou, J. Li, X. Du and B. Xu, Biomaterials, 2017, 129, 1-27. 5 M. de Loos, B. L. Feringa and J. H. van Esch, Eur. J. Org. Chem., 2005, 2005, 3615-3631.

6 A. Vintiloiu and J.-C. Leroux, J. Control. Release, 2008, 125, 179192.

7 Y. Sang and M. Liu, Mol. Syst. Des. Eng., 2019, 4, 11-28.

8 C. D. Jones and J. W. Steed, Chem. Soc. Rev., 2016, 45, 65466596.

9 C. D. Toderescu, C. Dinu-Pîrvu, M. V. Ghica, V. Anu, D. E. Popa and L. Vlaia, Farmacia, 2016, 64, 728-735.

10 J. Marto, D. Baltazar, A. Duarte, A. Fernandes, L. Gouveia, M. Militão, A. Salgado, S. Simões, E. Oliveira and H. M. Ribeiro, Pharm. Dev. Technol., 2015, 20, 710-715.

11 C. J. Martin, N. Alcock, S. Hiom and J. C. Birchall, Pharmaceutics, 2017, 9, 31

12 N. Aggarwal, S. Goindi and S. D. Mehta, AAPS PharmSciTech, 2012, 13, 67-74.

13 Y. Gao, C. Zhang, J. Chang, C. Yang, J. Liu, S. Fan and C. Ren, Biomater. Sci., 2019, 7, 1477-1485.

14 Y. Wang, J. Zhan, Y. Chen, S. Ai, L. Li, L. Wang, Y. Shi, J. Zheng and Z. Yang, Nanoscale, 2019, 11, 13714-13719.

15 T. Xu, Y. Cai, X. Zhong, L. Zhang, D. Zheng, Z. Gao, X. Pan, F. Wang, M. Chen and Z. Yang, Chem. Commun., 2019, 55, 7175-7178. 16 J. R. Fores, M. Criado-Gonzalez, A. Chaumont, A. Carvalho, C. Blanck, M. Schmutz, C. A. Serra, F. Boulmedais, P. Schaaf and L. Jierry, Angew. Chem. Int. Ed. Engl., 2019, 58, 18817-18822.

17 Y. Xu, X. Yang, A. K. Thomas, P. A. Patsis, T. Kurth, M. Kräter, K. Eckert, M. Bornhäuser and Y. Zhang, ACS Appl. Mater. Interfaces, 2018, 10, 14418-14425.

18 K. Lalitha, Y. S. Prasad, V. Sridharan, C. U. Maheswari, G. John and S. Nagarajan, RSC Adv., 2015, 5, 77589-77594.

19 A. Ghosh, M. Haverick, K. Stump, X. Yang, M. F. Tweedle and J. E. Goldberger, J. Am. Chem. Soc., 2012, 134, 3647-3650.
20 R. Das Mahapatra, J. Dey and R. G. Weiss, Langmuir, 2017, 33, 12989-12999.

21 H. Wang, Z. Feng and B. Xu, Chem. Soc. Rev., 2017, 46, 24212436.

22 J. Mayr, C. Saldías and D. Díaz Díaz, Chem. Soc. Rev., 2018, 47, 1484-1515.

23 S. Yagai and A. Kitamura, Chem. Soc. Rev., 2008, 37, 1520-1529. 24 L. Li, J. M. Scheiger and P. A. Levkin, Adv. Mater., 2019, 31, e1807333.

25 E. R. Ruskowitz and C. A. DeForest, Nat. Rev. Mater., 2018, 3, 117.

26 Z. L. Pianowski, Chem.- Eur. J., 2019, 25, 5128-5144.

27 E. R. Draper and D. J. Adams, Chem. Commun., 2016, 52, 81968206.

28 X. Xiao, J. Hu, X. Wang, L. Huang, Y. Chen, W. Wang, J. Li and Y. Zhang, Chem. Commun., 2016, 52, 12517-12520.

29 K. Peng, I. Tomatsu and A. Kros, Chem. Commun., 2010, 46 4094-4096.

30 P. Fatás, J. Bachl, S. Oehm, A. I. Jiménez, C. Cativiela and D. Díaz Díaz, Chem. - Eur. J., 2013, 19, 8861-8874.

31 M. J. Clemente, R. M. Tejedor, P. Romero, J. Fitremann and L. Oriol, New J. Chem., 2015, 39, 4009-4019.

32 Z. L. Pianowski, J. Karcher and K. Schneider, Chem. Commun., 2016, 52, 3143-3146.

33 C.-W. Chu and B. J. Ravoo, Chem. Commun., 2017, 53, 1245012453.

34 J. Karcher and Z. L. Pianowski, Chem. - Eur. J., 2018, 24, 1160511610.

35 H. Meier, Angew. Chem. Int. Ed. Engl., 1992, 31, 1399-1420. 36 D. C. Duncan and D. G. Whitten, Langmuir, 2000, 16, 64456452

37 S. Miljanić, L. Frkanec, Z. Meić and M. Zinić, Langmuir, 2005, 21, 2754-2760.

38 S. Miljanić, L. Frkanec, Z. Meić and M. Žinić, Eur. J. Org. Chem., 2006, 2006, 1323-1334.

39 J. Eastoe, M. Sánchez-Dominguez, P. Wyatt and R. K. Heenan, Chem. Commun., 2004, 2608-2609.

40 E. R. Draper, E. G. B. Eden, T. O. McDonald and D. J. Adams, Nat. Chem., 2015, 7, 848-852.

41 A. Srivastava, S. Ghorai, A. Bhattacharjya and S. Bhattacharya, J. Org. Chem., 2005, 70, 6574-6582.

42 M. J. Clemente, R. M. Tejedor, P. Romero, J. Fitremann and L. Oriol, RSC Adv., 2012, 2, 11419-11431.

43 J. Baillet, V. Desvergnes, A. Hamoud, L. Latxague and P. Barthélémy, Adv. Mater., 2018, 30, 1705078.

44 S. Ziane, S. Schlaubitz, S. Miraux, A. Patwa, C. Lalande, I. Bilem, S. Lepreux, B. Rousseau, J.-F. Le Meins, L. Latxague, P. Barthélémy and O. Chassande, Eur. Cells Mater., 2012, 23, 147-160.

45 D. Jain, A. Karajic, M. Murawska, B. Goudeau, S. Bichon, S. Gounel, N. Mano, A. Kuhn and P. Barthélémy, ACS Appl. Mater. Interfaces, 2017, 9, 1093-1098.

46 A. Patwa, J. Labille, J.-Y. Bottero, A. Thiéry and P. Barthélémy, Chem. Commun., 2015, 51, 2547-2550.

47 L. Latxague, A. Gaubert, D. Maleville, J. Baillet, M. A. Ramin and P. Barthélémy, Gels, 2016, 2, 25.

48 L. Latxague, M. A. Ramin, A. Appavoo, P. Berto, M. Maisani, C. Ehret, O. Chassande and P. Barthélémy, Angew. Chem. Int. Ed. Engl., 2015, 54, 4517-4521.

49 M. A. Ramin, L. Latxague, K. R. Sindhu, O. Chassande and P. Barthélémy, Biomaterials, 2017, 145, 72-80.

50 K. Ferré-Filmon, L. Delaude, A. Demonceau and A. F. Noels, Eur. J. Org. Chem., 2005, 2005, 3319-3325. 
